\title{
Two Worldviews Regarding Chinese American Names
}

\author{
Emma Woo Louie \\ Palo Alto, California
}

\begin{abstract}
The one-language one-nation concept that arose as part of the rise in nationalism in China is alive and well in America. The existence of two worldviews and the growing dominance of Mandarin speakers in the Chinese American population have implications for Chinese Americans whose names, especially those of Cantonese and other dialect origins, do not comply with Chinese standardized spelling rules. Nevertheless, non-Mandarin names and non-Mandarin sounding surnames constitute links to the regionalects of China.
\end{abstract}

\section{Introduction}

It has been a privilege to have conversed with Ed Lawson by email for many years on the subject of Chinese name traditions and Chinese American naming practices. He has been my mentor; when he recommended me to be one of the speakers at the 2006 ANS annual meeting in Albuquerque, I felt more confident than ever in being able to share some thoughts about Chinese American names. Writing to Ed has made me aware that there are two worldviews regarding the spelling of Chinese names as well as American family names of Chinese origin.

According to the first, the Chinese worldview, the characters of a Chinese name represent the true identity of its owner. And when the name is rendered into Roman letters, it is considered correctly spelled only when it is according to Mandarin and a standardized method. The standard method today is pinyin, the official spelling system of the People's Republic of China. It has replaced the Wade-Giles system, which was in popular use before 1979 for romanizing Mandarin and was considered for many decades as the correct way to spell a Chinese name.

Names 55.4 (December 2007): 363-371

ISSN: 0027-7738

(C) 2007 by The American Name Society 
The family name 趄 is Zhao in pinyin but Chao in Wade-Giles. WadeGiles is still used in Taiwan where it is known as the traditional spelling method. It seems to me that the Chinese worldview goes hand in hand with the one language-one nation concept that arose with the rise of nationalism (DeFrancis 1950, 55-84; 1984, 56, 227; Louie 1998, 76, 169, 201).

The second worldview comes from the American or English-speaking perspective that recognizes the legitimacy of spelling variations for the same name, whether a family name or a given name. Therefore the name used by an individual, as long as it is not used for criminal purposes, is the real name. According to Ben Tucker (p. c.), Chief of the Office for Descriptive Cataloging Policy at the Library of Congress, there is "no U.S. academy that would set an official policy on romanization systems for all citizens" to use for name spelling.

Since individuals have the right to decide on the spelling and pronunciation of their family names, wide variations in spelling occur for Chinese family names because of differences in dialect pronunciation. Spelling for the family name 陳 (or 陈), for example, can be Chan, Chen, Chern, Chin, Chinn, Chun, Tan, Tchen, Ting, Tran, and Zung. Each is the correct spelling for its owner and family and, from the American world-view, correctness in spelling should not be confused with the origin of the family name (Hanks 2003, xi).

\section{The Chinese Language}

It is important to recall that, while the Chinese language consists of several major regional speech groups there are uniform traditional and simplified scripts which can be read by all literate persons regardless of their particular speech region. Both traditional and simplified scripts existed long before the PRC began simplifying thousands of characters into fewer strokes as part of its language reforms. The traditionally written family name 葉 has been simplified to 叶. Traditional script is still used in Taiwan and most countries to which Chinese have immigrated.

The Chinese language is usually described as either a family of languages or as one language consisting of several major dialects. The first description is anathema to those who believe in the one language-one nation concept. John DeFrancis, in recognizing the diversity of the spoken language, uses the term "regionalect" to describe the regional speech groups (1984, 54-58). Almost all the regionalects are represented in Chinese American names: Mandarin, which is spoken in most of China; several southern regionalects such as Cantonese (plus numerous subdialects spoken 
in Guangdong province), $W u$ (prominent in Shanghai), Min (including Amoy, Hokkien, Teochew, and Haina), and Hakka.

In 1913, Mandarin, based on the Beijing dialect, was selected as China's national language under the Republic of China's language reform efforts. There was fear among some, however, that having a national language would eliminate the regionalects. They wanted people to be able to speak both their local speech and Mandarin. The non-Mandarin regionalects did not die out but, ironically, these are now considered a barrier to national unity since the PRC's official policy is to promote a standard written and standard spoken language (DeFrancis, 1984, 224-28).

Thus we find that many diverse spellings of American family names of Chinese origin are not necessarily variations of Mandarin, but rather the result of a particular regionalect.

\section{Before 1950}

Historically, Cantonese-sounding names have predominated among Chinese Americans since this regionalect and several of its subdialects were brought here when Chinese immigration began in the mid-1800s. Most immigrants came from the Seiyap region, the area of "four counties speech." Toishan county (Taishan, in pinyin), in particular, contributed the majority of early immigrants (Chinn et al. 1969, 20; Sung 11-13). Since names were spelled according to dialect pronunciation rather than to dictionary spelling, Cantonese dialect sounds occur in most American family names of Cantonese origin. The differences in speech between the rural Seiyap and the Cantonese spoken in Hong Kong and the provincial capital can be seen in the following surnames:

$\begin{array}{cll}\text { Surname Character: } & \text { Cantonese: } & \text { Seiyap: } \\ \text { 李 } & \text { Lay, Laye } & \text { Lee } \\ \text { 雷 } & \text { Lui } & \text { Louie } \\ \text { 譚, 谭 } & \text { Tom } & \text { Hom } \\ \text { 陳, 陈 } & \text { Chan, Chun } & \text { Chin, Chinn } \\ \text { 謝, 谢 } & \text { Jay, Tse } & \text { Dear, Der } \\ \text { 獻 } & \text { Kwong } & \text { Fong } \\ \text { 司徒 } & \text { Szeto } & \text { Soo, Hoo } \\ \text { 甄 } & \text { Yan } & \text { Gin, Ginn }\end{array}$

Many family names were also Americanized in spelling for the early established families: Chinn, Jay, Dear, Lay, Laye, Lee, Louie, and Ginn. 


\section{Names 55.4 (December 2007)}

New surnames developed for the American-born second generation since the first generation - the immigrant generation - tended to keep the family name first when writing their Chinese names in English. It could be the father's two-character given name, as in Typond-from Lee Typond who settled in New York City; it could be the family name followed by a one-character given name, as in Leong Way-who settled in San Francisco, but more frequently, the last word of the two-character given name-such as Bow, Hing, and Jig-became the patronymic. Even though the twocharacter given name is one given name, this practice came about because it became popular to write each character of the name as a separate word. The Chinese called these patronymics "turned-around names."

Other regionalects were represented in Chinese American names but were fewer in number; Cantonese was dominant as the language in Chinese American communities due to the Chinese exclusion laws (1882 through 1943) and the restrictions on immigration from Asia, which were not repealed until 1965. Despite the restrictions, however, many Chinese gained entry as merchants, children of American citizens, college students, and foreign-born brides of U.S. citizens.

Before 1950, Mandarin-sounding names-mostly spelled according to Wade-Giles-existed primarily among foreign-born college and university students. After the founding of the PRC in 1949, the few thousand Chinese who chose to remain in the U.S. were given permanent resident status. This marked the beginning of demographic changes in the Chinese American population (Lee 89-93, 103). Differences in pronunciation between standard Cantonese and Mandarin are seen in the following surnames:

$\begin{array}{lll}\begin{array}{l}\text { Surname } \\ \text { Character }\end{array} & \text { Standard } & \text { Mandarin } \\ \text { 陳, 陈 } & \text { Cantonese } & \text { Wade-Giles } \\ \text { 許, 许 } & \text { Hui } & \text { Chen } \\ \text { 張, 张 } & \text { Jeung } & \text { Hsu } \\ \text { 林 } & \text { Chang } \\ \text { 黃 } & \text { Wam, Lum } & \text { Lin } \\ \end{array}$

Since 1968

American family names of Chinese origin became much more representative of the Chinese spoken language after immigration restrictions were lifted and after the end of the Vietnam War in 1975. The family name 黃 is now spelled as Huang, Huynh, Hwang, Hwong, Oei, Waung and Wong. 
Resumed relations between the U.S. and the PRC in 1978 resulted in China and Taiwan receiving separate annual quotas of 20,000 immigrants beginning in 1981 (Randall 2001). A tremendous influx of new immigrants occurred and, between 1990 and 2000, the foreign-born among Chinese Americans increased by 87 percent (Grieco 2004). A large pool of pinyinspelled names was created by immigrants from mainland China while those from Taiwan added to the existing pool of Wade-Giles spelled names. Although Wade-Giles and pinyin agree in spelling for many family names, many names are now spelled very differently in pinyin:

$\begin{array}{cll}\text { Surname Character } & \text { Wade-Giles } & \text { Pinyin } \\ \text { 張, 张 } & \text { Chang } & \text { Zhang } \\ \text { 全 } & \text { Chuan } & \text { Quan } \\ \text { 熊 } & \text { Hsiung } & \text { Xiong } \\ \text { 何 } & \text { Ho } & \text { He } \\ \text { 蔡 } & \text { Tsai } & \text { Cai }\end{array}$

It seems safe to say that over 350 Han Chinese family names have been brought to America and that three times as many surname variants exist. Some family names are spelled in numerous ways, some only one, while different family names may share the same spelling.

Wong (黄) has long been considered a most popular Chinese American surname along with Lee and Chan (Leong 55. [Years ago I was told the author's name is not a real name; it means "two persons" in Cantonese.]). Wong ranked 457 out of 5,000 common surnames listed in the 1984 Report of Distribution of Surnames in the Social Security Number File, making it the most popular name of Chinese origin. Although Lee ( $L i$ 李) ranked 26, there is no way to determine the number of Chinese Americans possessing this surname (Louie 1998, 149, 158-60).

Since hundreds of thousands of Mandarin speakers have emigrated in recent decades (Grieco 2004), so it is not surprising that Chen is now the most common American family name of Chinese origin. Matthew Falkenstein, in his report based on the 2000 federal census, listed 25 surnames as common for Asian and Pacific Islander Americans (API). Chen, number 5 on the list, nosed out Wong, at number 6. (Nguyen, the most common Vietnamese family name, was number one). Chen still outnumbered Wong when these surnames were combined with their respective counterparts. Chen and the Cantonese-sounding Chan, at number 10, had a count of 
165,827 whereas Wong and the Mandarin-sounding Huang, at number 19, totaled $140,496(2002,949)$. These four spelling variants also represent other family names, but the majority of Chens and Chans are likely to have the family name 陳, 陈; most Wongs and Huangs share the family name 黄.

Not surprisingly, Lee was not listed. As Falkenstein reported, "60\% of persons with the surname LEE self identify race as something other than API" (948). The other eleven surnames of Chinese origin in this reportmost are also Korean American names-show that Mandarin spelling prevails: Chang, Yang, Li, Lin, Liu, Wu, Lam, Ho, Yu, Chung, and Choi. The surnames Lam, Ho, and Choi are found among Cantonese speakers but $\mathrm{Ho}$ is also Wade-Giles spelling for this family name, which is undoubtedly 何 in Chinese.

\section{Updating Names into Pinyin}

After pinyin was accepted in 1979 as the official transcription for Mandarin, American news media began using it for citing placenames and personal names of the PRC. But the Wade-Giles spelled names of Taiwan were usually respected and not respelled. In contrast, Chinese Americans who believed in standardized spelling for Chinese names began to pinyinize non-Mandarin sounding names. The names of some of the noteworthy early immigrants were respelled, based on the characters to the Chinese name.

One method of pinyinizing is to omit the name used by the individual when citing Chinese resource materials. For example, Chin Gee Hee, who resided in Seattle, Washington from 1868 to 1905 , was known for building a railroad in his native Toishan county; even his name reflects Toishan speech (Jue 1880-1983). Chin became Chen Yixi in a book about emigration from this county (Hsu 2002, 11, 22, 27, 31). A friend told me she had to pinyinize her relatives' Cantonese-sounding names in her master's thesis in Asian American Studies because she knew the characters to their names.

Another method places the pinyinized Chinese name first, followed by the real name in parenthesis (Lai 2005, 19), as in "Wen Xiongfei (Won Hung Fei)." This would make the pinyin name the prime symbol of identity. Even well known Chinese Americans who were not known by their Chinese names did not escape being identified by a pinyinized name: the author Maxine Hong Kingston was listed in at least one book as "Tang, Tingting (Kingston, Maxine Hong)" (Lai 1986, xv, 137, 148, 150).

Even the advice given in the 14th edition of the Chicago Manual of Style echoed the Chinese viewpoint. It suggested using Wade-Giles for 
"names of persons who are no longer living and pinyin for those who are still alive." Or "spell names in pinyin followed by the old spellings in parentheses" $(1993,9.96)$.

By comparison, when the Library of Congress finished switching from Wade-Giles to pinyin for recataloging Chinese names in 2000, its policy did not include respelling all Wade-Giles names. According to Philip Melzer (p. c.), of the Regional and Cooperative Cataloging Division at the Library of Congress, pinyin is used mainly for transcribing Chinese language materials and for spelling Chinese names that had not been previously spelled in Roman letters. Moreover, when an author is known to prefer Wade-Giles spelling, conversion to pinyin will not take place.

I have been told that respelling non-Mandarin names into pinyin or Wade-Giles enables Chinese speakers to decipher the characters. This may be true for a few family names, such as Liang (梁) and $\mathrm{Hu}$ (胡) but unlikely for given names, which are composed of ordinary words that include many homophones. For the most part, the exact characters for a name cannot be determined by the spelling, regardless of methodology. If the surname character is unknown, a dictionary is not likely to be helpful because different family names have the same spelling. Moreover, many spelling variants are not found in dictionaries.

The late, renowned Chinese American linguist Yuen Ren Chao put it succinctly $(1968,47)$ when he wrote that transcribing Chinese characters "work only one way and are not reversible" when they are transcribed into Roman letters. Incidentally, this venerable gentleman's name has recently been pinyinized to "Zhao Yuanren" without mentioning the name he used most of his life and in all his writings (China Daily, 2003).

\section{Implications for Real Names}

It appears that any noteworthy person with a Chinese name is fair game to having his or her name changed into pinyin. This ignores the fact that immigrants usually acquiesce to the name practices of the adopted country, just as foreigners living in China would adopt a Chinese name as a matter of course. The rich diversity in spelling family names of Chinese origin fairly bursts with information about history, language, and culture. But the arbitrary respelling of real names into pinyin erases the true identity of an individual and it also skews Chinese American history. Pinyinizing the names of only noteworthy individuals denigrates the Cantonese and other regionalect presence and their contributions to America. 


\section{Names 55.4 (December 2007)}

Archeological finds in this country are also subject to pinyin spelling, but, without explanation or use of square brackets, a Mandarin-sounding name could be mistaken for an actual name. Anthropologist Priscilla Wegars and her colleagues avoid this problem by including the words "in pinyin" before the translation. For example, reporting words on a tombstone, a translator wrote "Inscription reads, in pinyin, 'Liao Tong Shing was from the village of Wai Ba.' Translated by Xiao Yun Yao at the University of Idaho's Asian American Comparative Collection" (Rouse 2005, 96).

For the reader who is unfamiliar with the spelling of Chinese names, adding the words "in pinyin" is helpful, as in Chang-lin Tien (Tian Zhanglin, in pinyin). This places the real name in the position of honor. Another method that also respects a real name is to place the pinyinized name in brackets so as to indicate that it is not the original spelling, as in Chang-lin Tien [Tian Zhanglin]. Placing the Chinese characters in parenthesis: Chang-lin Tien (田长霖) eliminates pinyinizing names. But the best method is to regard an American name of Chinese origin as a regular American name.

There can be no doubt that Mandarin will replace Cantonese, if it hasn't already, as the language of Chinese America. Should the demise of the nonMandarin regionalects occur in China in the future, American surnames spelled according to Cantonese, Shanghai, Hokkien, and other regionalect pronunciations will be living reminders of the language that once existed in the country of origin.

\section{References}

Chao, Yuen Ren. 1968. Language and Symbolic Systems. New York: Cambridge Univ. P.

China Daily. 2003. "Humanities Reborn at Tsinghua." http://www.china daily.com.cn/en/doc/2003-12/30/content_294411.htm

Chinn, Thomas, H. Mark Lai, and Philip P. Choy, eds. 1969. A History of the Chinese in California: A Syllabus. San Francisco: Chinese Historical Society of America.

DeFrancis, John. 1950. Nationalism and Language Reform in China. Princeton, NJ: Princeton Univ. P. . 1984. The Chinese Language: Fact and Fantasy. Honolulu: Univ. of Hawaii P. 
Falkenstein, Matthew R. 2002. "The Asian and Pacific Islander Surname List: As Developed From Census 2000." U.S. Census Bureau. Pp. 946-50. (Paper presented at the 2002 Joint Statistical Meetings). http://www.amstat.org/sections/SRMS/proceedings/y2002/Files/JSM2 002-000501.pdf

Grieco, Elizabeth. 2004. "The Foreign Born from China in the United States." US in Focus, January 1, 2004. Migration Information Source. http://www.migrationinformation.org/Usfocus/display.cfm?id=190

Hanks, Patrick, ed. 2003. Dictionary of American Family Names. New York: Oxford Univ. Pp. ix-xxii.

Hsu, Madeline Y. 2002. "California Dreaming: Migration and Dependency." Chinese America: History and Perspectives 2002. San Francisco: Chinese Historical Society of America. Pp. 9-31.

Jue, Willard G. Guide to the Willard G. Jue Papers 1880-1983. University of Washington Libraries, Special Collections. http://www. lib.washington.edu/specialcoll/findaids/docs/papersrecords/

Lai, Him Mark, comp. 1986. A History Reclaimed: An Annotated Bibliography of Chinese Language Materials on the Chinese of America, Russell Leong and Jean Pang Yip, eds. Los Angeles: University of California, Asian American Studies Center.

. 2005. "A Brief Historical Overview of Wen Xiongfei's Times." Chinese America: History and Perspectives 2005. San Francisco: Chinese Historical Society of America. P. 9.

Lee, Rose Hum. 1960. The Chinese in the United States of America. Hong Kong: Hong Kong Univ. P.

Leong, Gor Yun. 1936. Chinatown Inside Out. New York: Barrows Munsey.

Louie, Emma Woo. 1998. Chinese American Names: Tradition and Transition. Jefferson, NC: McFarland.

Randall, Vernellia R. 2001. "Affecting Asian Pacific Americans." Asian Pacific Americans and Immigration Law. The University of Dayton School of Law. http://academic.udayton.edu/race/02rights/immigr05. $\mathrm{htm}$

Rouse, Wendy L. 2005. "Archeological Excavations at Virginiatown's Chinese Cemeteries." In Sue Fawn Chung and Priscilla Wegars, eds., Chinese American Death Rituals: Respecting the Ancestors. Lanham, 